\title{
SHEAR AND FLEXURAL BEHAVIOR OF FERRO CEMENT DEEP BEAMS
}

\author{
Md Ihtesham Hussain ${ }^{1}$,Vaijanath Halhalli ${ }^{2}$, P.M.B Raj kiran Nanduri ${ }^{3}$ \\ ${ }^{1,3}$ Lecturer, Department of Civil Engineering, Adama Science and Technological University, ETHIOPIA \\ ${ }^{2}$ Professor, Department of Civil Engineering, PDA College of Engineering Gulbarga \\ ihtesham89@gmail.com,vaijanathhalhalli@yahoo.com,rajkiran.n1987@gmail.com
}

\begin{abstract}
The recent application of Ferro cement includes prefabricated roofs elements, load bearing panels, bridge decks and others. However there have been many structural applications in different parts of the world especially in eastern hemisphere considerable efforts have been made by many individuals and research organization around the world to study the engineering of Ferro-cement. This present study deals with the behavior of Ferro cement deep beams under central point load. A total of 27 rectangular deep beams have been casted of dimension $125 \times 250 \mathrm{~mm}$ and the lengths of beams have been varied along with the variation of wire mesh and mortar strength. Before testing, the top surfaces of these beams were white washed, to get a clear picture of crack pattern. Along with these beams 27 cubes have been casted with the dimensions $7.06 \mathrm{~cm} \times 7.06 \mathrm{~cm} \times 7.06 \mathrm{~cm}$. the compressive strength of mortar is determined.
\end{abstract}

Keywords: Admixture, Deep Beams, Ferro cement, Shear Span.

\section{INTRODUCTION}

Ferrocement, a composite comprising cement mortar as the matrix and fine wire mesh as the reinforcement, has been regarded as a highly versatile construction material. The closer distribution and uniform dispersion of reinforcement transform the otherwise brittle matrix into a composite that exhibits superior performance over conventional reinforced concrete with respect to cracking, tensile strength, ductility and impact resistance.

Being thin-walled in nature Ferrocement has found to be most suited for structures like shells and folded plates, where the applied load is primarily carried through the action of in-plane shear and axial stress. When the out-of-plane action becomes predominant, Ferro cement in its traditional form behaves rather poorly because of its low flexural rigidity. Efforts have been made to increase the flexural performance of Ferrocement by introducing ribs and hollow cores, or resorting to a sandwich-type construction. Other alternatives include the use of thin-walled structural sections, typically employed for steel or fibre-reinforced polymer like box, channel, T- and Isections. The uniform distribution and high surface area to volume ratio of its reinforced results in better crack arrest mechanism i.e. the propagation of cracks are arrested resulting in high tensile strength of the material.

Deep beam is a beam having large clear span to depth ratio and shear span depth ratio less than 2.5 for concentrated load and less than 5.0 for distributed load. It is a reinforced concrete member in which the total span or shear span is exceptionally small in relation to its depth. Deep beams play a very significant role in design of mega and as well as small structures. Some times for architectural purposes buildings are designed without using any column for a very large span.

CIRIA is the Construction Industry Research and Information Association; it is non-profit distributing organization carrying out on Research work of behalf of its members. The CIRIA Guide simple rules for designing reinforced concrete deep beams of span/depth ratio below 2 for single span or 2.5 for multi-span The Guide has been prepaid by a team of designers and has been approve by a panel of assessors as authoritative statements of the art and of good practice in designing reinforced concrete deep beams.

Al-Kubaisy and Ned Well [1] studied on the location of the diagonal crack in ferrocement rectangular beams. The variables covered in the study were, a/d volume fraction and compressive strength of the mortar 'fcu'. The effect of the volume fraction, $\mathrm{Vf}$ on the location critical diagonal crack is not well defined. It is also concluded that the ACI-ASCE committee 326 expression for predicting the location of the diagonal crack in conventional reinforced concrete beams underestimates the location for ferrocement beams with $\mathrm{a} / \mathrm{d}=$ 1.0 and over estimates the location for beams with $\mathrm{a} / \mathrm{d}>1.5$.

Mansur, M.A. and Ong, K.C.G. 1987 [2] conducted shear tests on the ferrocement beam sections and concluded that, the behavior of these structural sections is similar to that of structural reinforced ferrocement beams. It is also mentioned that the ferrocement beams exhibit numerous cracks and 
sections are serviceable up to $90 \%$ of the ultimate load. Naaman and Shah's [3] (1974) work indicated that the stress level at which the first crack appeared and the crack spacing were a function of the specific surface of reinforcement. The ultimate load of the ferrocement specimen was the same as the load carrying capacity of the reinforcement in that direction. Desayi [4] proposed a semi empirical formula for predicting the shear strength of ferrocement elements. Mansur and Paramasivam (1986) [5] proposed a method to predict the ultimate strength of ferrocement in flexure based on the concept of plastic analysis where ferrocement is considered as a homogenous perfectly elastic-plastic material. It was found that the ultimate moment increase with increasing matrix grade (decreasing water cement ratio) and increasing volume fraction of reinforcement.

Till today no codal formula is available to assess the shear strength of ferrocement elements. Thus there is a need to verify, where the shear resistance equations given by existing codes of practice for reinforced concrete can be extended to ferrocement also?

\section{EXPERIMENTAL PROGRAMME}

\subsection{Objectives}

1. The aim is to study the shear and flexural behavior of ferrocement deep beams and to study the effect of the following parameter.

a) Volume fraction of reinforcement $\left(V_{f}\right)$

b) Shear span to overall depth ration $(\mathrm{a} / \mathrm{h})$

c) Cube compressive Strength $\left(\mathrm{f}_{\mathrm{cu}}\right)$

2. To study the load - deflection relationship and shear behavior.

3. To compare the test ultimate load $\left(\mathrm{V}_{\mathrm{u}}\right)$ with the design code (ACI 318-83) and CIRIA guide.

4. To compare the test cracking shear stress $\left(\tau_{\mathrm{u}}\right)$ with the design code (ACI 318-83) and CIRIA guide and too generate a linear empirical equation for predicting the ultimate strength of ferro-cement deep beams.

\section{EXPERIMENTAL INVESTIGATION}

The experimental investigation includes casting and testing of 27 rectangular deep beams and cubes. Three groups of specimens were casted. In Group-A nine beams of size $120 \mathrm{~mm} \times 250 \mathrm{~mm}$ were tested. The parameter considered in this group is varying shear span to depth ratio $(\mathrm{a} / \mathrm{h})$ while the wire mesh $(\mathrm{N})$ and mortar strength $\left(\mathrm{f}_{\mathrm{cu}}\right)$ were kept constant. In Group $-\mathrm{B}$, again nine beams of same size were tested. The parameter considered in this group is varying mortar strength $\left(\mathrm{f}_{\mathrm{cu}}\right)$ while the shear span to depth ratio $(\mathrm{a} / \mathrm{h})$ and wire mesh (N) were kept constant. In the third group nine beams of size $120 \mathrm{~mm} \times 250 \mathrm{~mm}$ were tested. The parameter considered in Group-C is number of wire $\operatorname{mesh}(\mathrm{N})$ while keeping other parameters unvaried.

\section{MIX PROPORTIONS}

After deciding all the parameters and water cement ratio, dosage of super-plasticizers was fixed. Throughout the whole program the cement to sand ratio was varied from 1:1 to $1: 2$ and w/c ratio from 0.25 to 0.4 based upon the mortar strength required and to obtain the desired workability a superplasticizer (HRWA) was used in all the mixes.

\section{TEST PROCEDURE:}

All beams are simply supported on two edges. All specimens were tested under concentrated single point load. The test setup is shown in the Figure 1. The deflections and the corresponding applied loads were recorded at the specified displacement intervals.

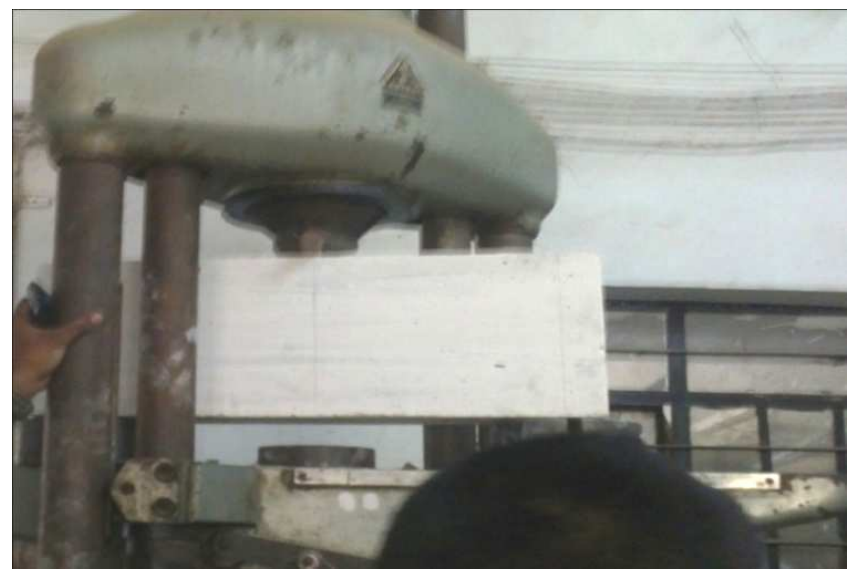

Fig 1 Test setup to determine shear and flexural strength 


\section{RESULTS AND DISCUSSIONS}

Table 1: Details of test specimens

\begin{tabular}{|c|c|c|c|c|c|}
\hline $\begin{array}{c}\text { Beam } \\
\text { designation }\end{array}$ & $\begin{array}{c}\text { Parameter to be } \\
\text { investigated }\end{array}$ & $\begin{array}{l}\text { Shear span to } \\
\text { depth ratio } \\
(\mathbf{a} / \mathbf{d})\end{array}$ & $\begin{array}{l}\text { No. of layers of } \\
\text { wire mesh }(\mathbf{N})\end{array}$ & $\begin{array}{c}\text { Total volume } \\
\text { fraction of mesh } \\
\text { reinforcement }\left(V_{f}\right)\end{array}$ & $\begin{array}{c}\text { Cube } \\
\text { compressive } \\
\text { strength of motar } \\
\left(\mathbf{f}_{\mathrm{cu}}\right) \\
\mathrm{N} / \mathbf{m m}^{2}\end{array}$ \\
\hline A1 & \multirow{3}{*}{$\mathrm{a} / \mathrm{h}$} & 0.6 & 3 & 1.964 & 60 \\
\hline A2 & & 0.65 & 3 & 1.964 & 60 \\
\hline A3 & & 7.0 & 3 & 1.964 & 60 \\
\hline B1 & \multirow{3}{*}{$\mathrm{f}_{\mathrm{cu}}$} & 0.65 & 3 & 1.964 & 85 \\
\hline B2 & & 0.65 & 3 & 1.964 & 60 \\
\hline B3 & & 0.65 & 3 & 1.964 & 40 \\
\hline $\mathrm{C} 1$ & \multirow{3}{*}{$\mathrm{N}$} & 0.65 & 1 & 1.816 & 60 \\
\hline $\mathrm{C} 2$ & & 0.65 & 2 & 1.883 & 60 \\
\hline C3 & & 0.65 & 4 & 2.026 & 60 \\
\hline
\end{tabular}

\subsection{Load Deflection Relationship:}

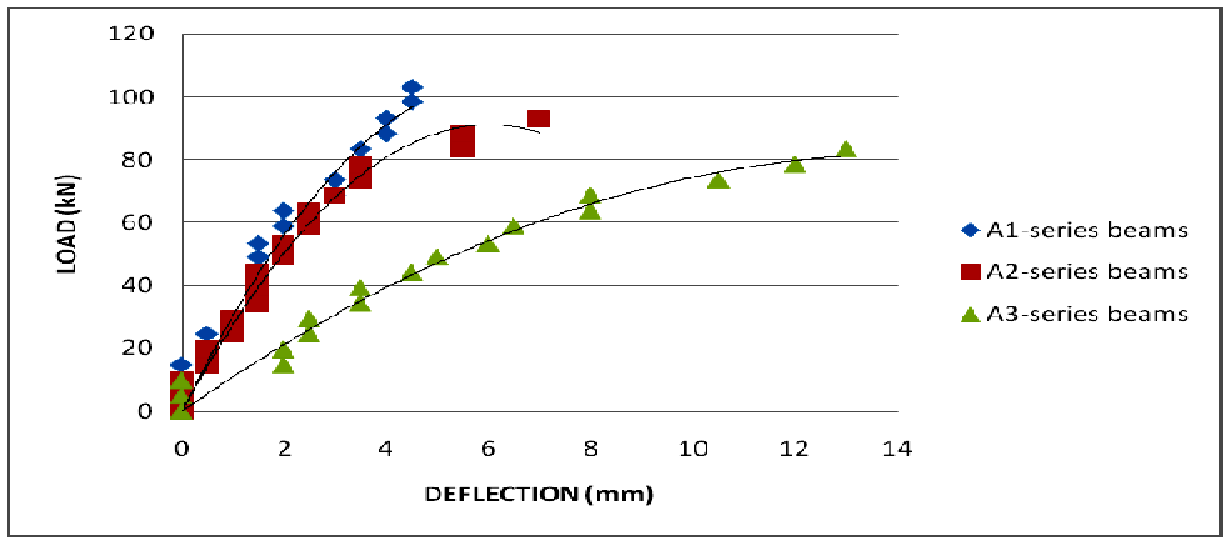

Fig 2 Load-Deflection Behavior of Beams of Group-A

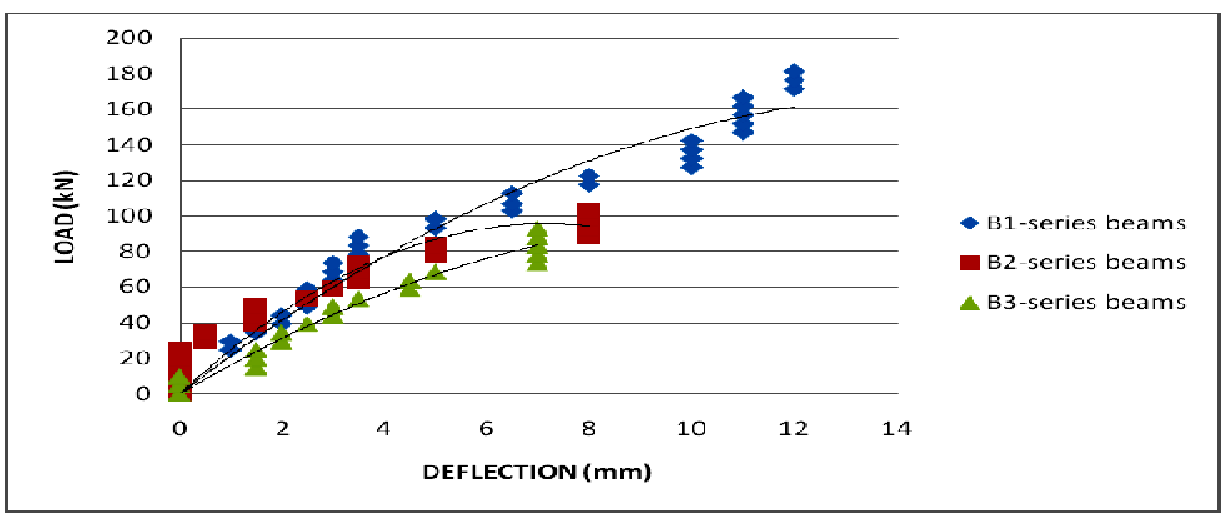

Fig 3 Load deflection behavior of beams of Group-B 


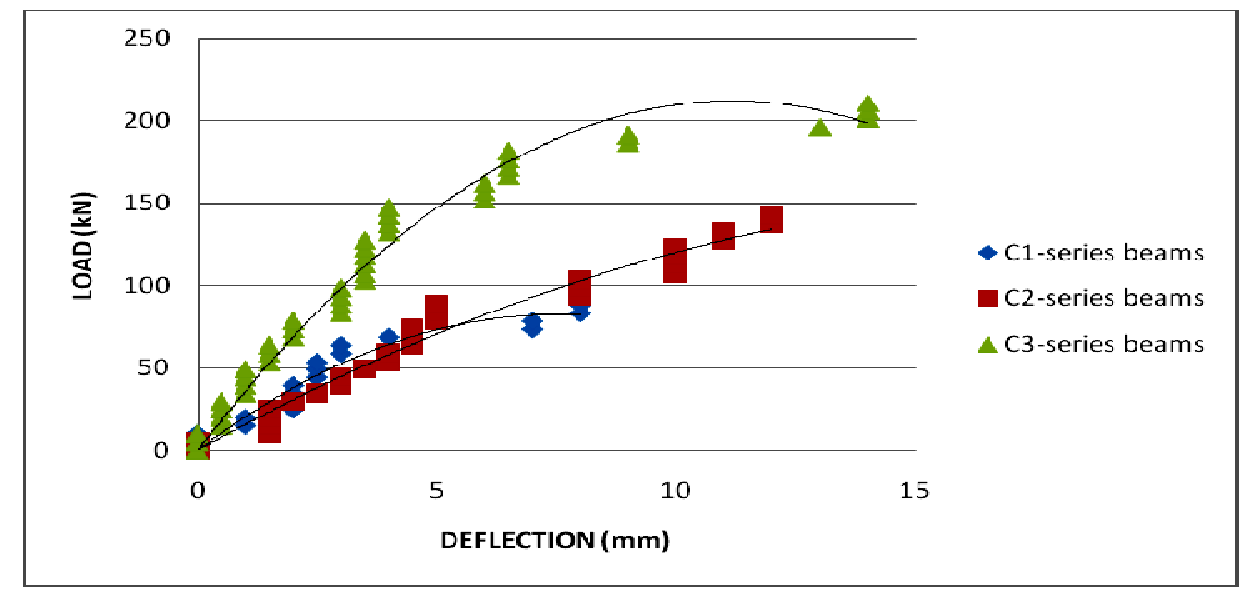

Fig 4 Load deflection behavior of beams of Group-C

\subsection{Cracking Behavior and Modes of Failure}

In all specimens, flexural cracks occurred first irrespective of the study parameters of the present study. As the load was increased, additional vertical cracks appeared on beam surface, followed by the formation of diagonal cracks. In the present study, diagonal tension cracks in the specimens with $\mathrm{a} / \mathrm{h}>0.65$ generally originated as vertical flexural cracks that extended from the tensile surface of the beam to slightly above the level of the bottom layer of wire mesh then became inclined and propagated towards the nearer concentrated load. In cases of beams with shorter shear span $(\mathrm{a} / \mathrm{h}<0.65)$. Diagonal tension cracks originated at about mid-depth of the beam and then progressed towards nearer concentrated load and tensile reinforcement.

The other type of failure occurred in beams with $\mathrm{a} / \mathrm{h}=0.7$. This was typically shear compression failure characterized by crushing of the mortar near the concentrated load.

\subsection{Effect of study parameters on the ultimate shear}

\section{strength}

The figure 5 shows that with the increase in the volume fraction of reinforcement increases the shear strength of ferrocement beams when the dimensions of the beam and mortar grade aren't varied.

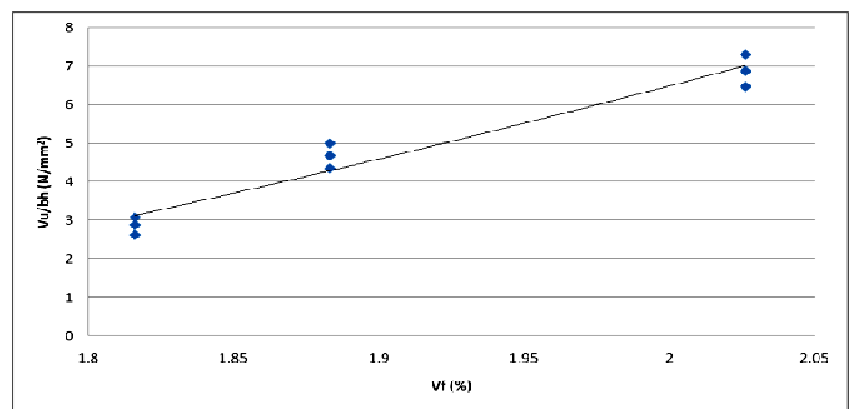

Fig5 Comparison of test parameter volume fraction of

$$
\text { reinforcement }\left(\mathrm{V}_{\mathrm{f}}\right) \text { and }\left(\frac{V_{u}}{b h}\right)
$$

The figure 6 shows that with the decrease in $\mathrm{a} / \mathrm{h}$ ratio increases the ultimate shear strength of ferrocement deep beams that means the length of the beam is only varied and other parameters such as number of mesh layers and grade of mortar are kept constant.

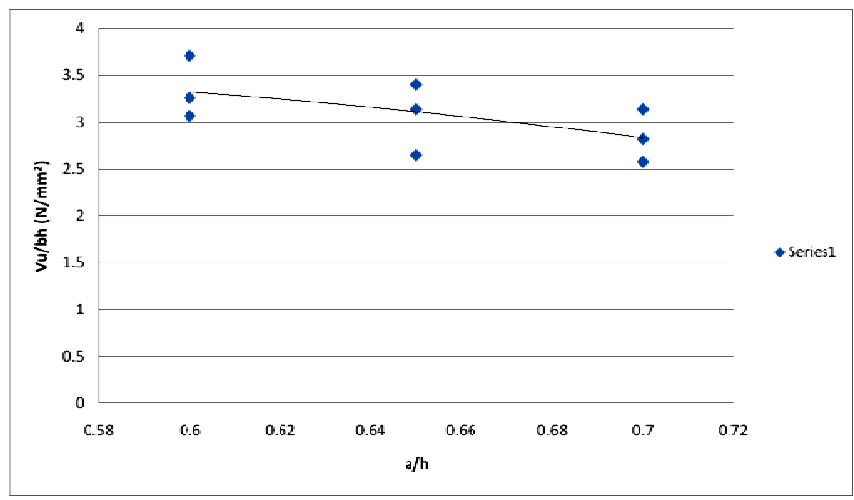

Fig 6 Test parameter shear span to depth ratio (a/h) $v / s \frac{V_{u}}{b h}$ 
The figure7 below shows that with the increase in the mortar strength the ultimate strength of ferrocement deep beams increases and the other test parameters are kept unvaried during this analysis. The graph shows a linear variation of shear strength with mortar grade.

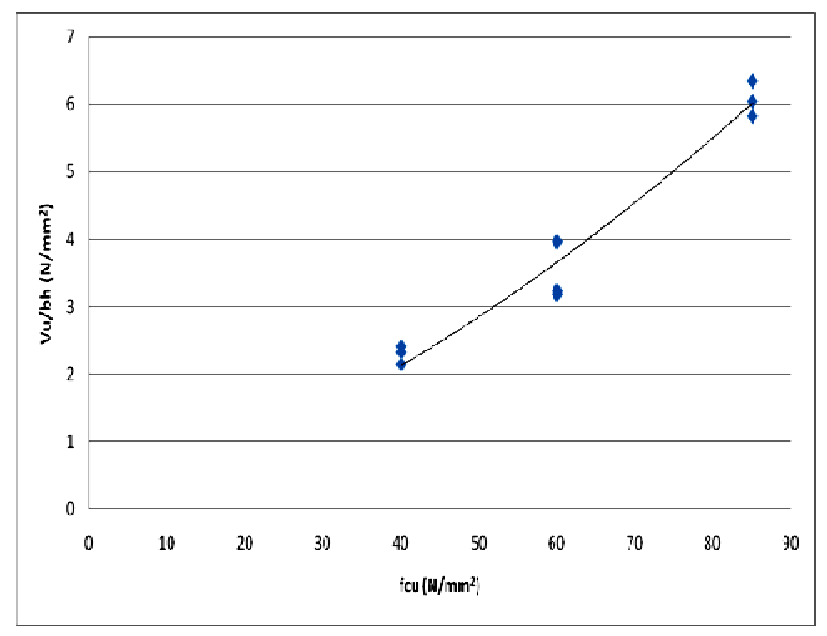

Fig 7 Test parameter mortar strength $\left(f_{c u}\right) v / s \frac{V_{u}}{b h}$

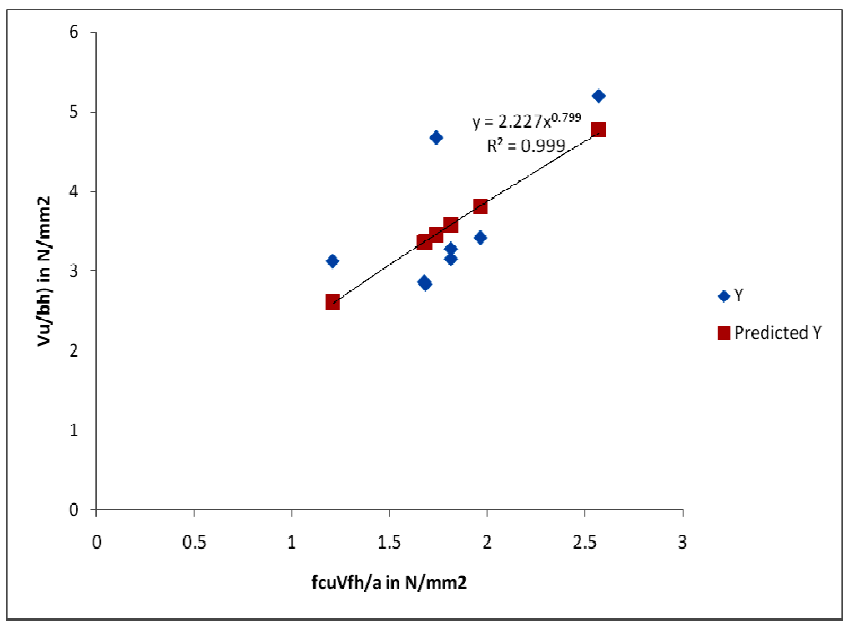

Fig 8 Regression between the parameters $\frac{V_{u}}{b h}$ and $\frac{f_{c u} V_{f} h}{a}$

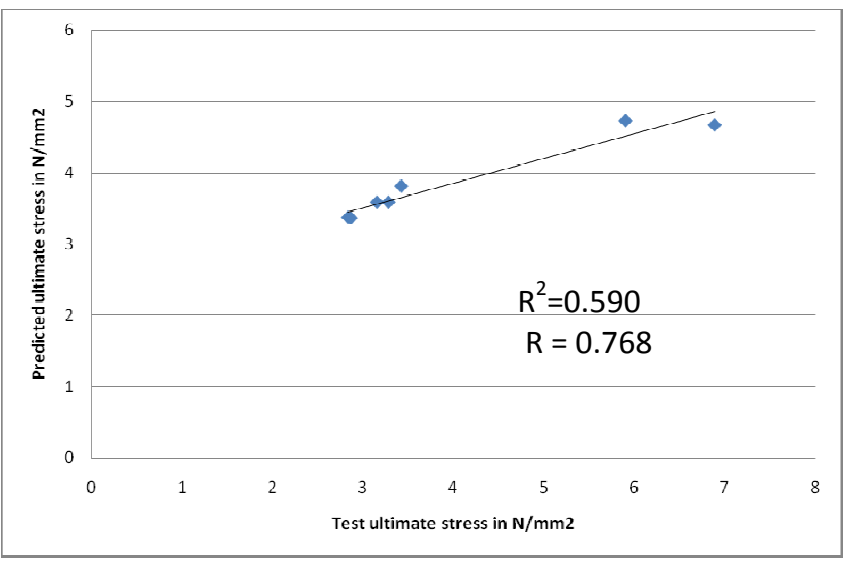

Fig 9 Comparison of Test and Predicted ultimate shear stresses

\subsection{Comparison of experimental ultimate load with}

\section{design codes:}

The codal provision for the ultimate strength of ferrocement deep beam given in ACI 318-83 is considered in the present analysis.

$$
\mathrm{V}_{\mathrm{uc}}=0.16 \mathrm{bd} \sqrt{\mathrm{f}_{\mathrm{cu}}}+17.2 \frac{\mathrm{bpV}_{\mathrm{cr}} \mathrm{d}^{2}}{\mathrm{M}_{\mathrm{cr}}}
$$

Where

$\mathrm{V}_{\mathrm{cr}} \quad=$ Cracking load in $\mathrm{KN}$

$\mathrm{p}=$ Reinforcement ratio $=\mathrm{A}_{\mathrm{st}} / \mathrm{bd}$

$\mathrm{M}_{\mathrm{cr}}=$ Bending moment $\mathrm{N}-\mathrm{mm}$

\subsection{CIRIA Guide:}

According to CIRIA Guide:

$\mathrm{V}_{\mathrm{uc}}=\left[\lambda_{1} \times \mathrm{V}_{\mathrm{x}}+\beta\left(\mathrm{V}_{\mathrm{ms}}+\mathrm{V}_{\mathrm{oh}}+\mathrm{V}_{\mathrm{wv}}\right)\right] \times \mathrm{bh}$

Where

$\mathrm{h}=$ depth of beam $\lambda_{1}=0.44$ for normal weight concrete.

$\mathrm{V}_{\mathrm{x}}=$ concrete shear parameter as tabulated in table -4 of the CIRIA guide.

$\mathrm{V}_{\mathrm{ms}}=$ Main steel shear stress parameter as tabulated in Table -6 of the CIRIA guide.

$\mathrm{Vwh}=$ Horizontal web steel as tabulated in table -7 of the CIRIA guide

Vwv $=\quad$ Vertical web steel as tabulated in table -8 of the CIRIA guide

$\beta=1$ for deformed bars. 


\subsection{Comparison of test ultimate shear stress $\left({ }^{\tau_{\mathrm{u}}}\right)$}

with design code:

\section{1) As per ACI 318-83}

The available equations for predicting the cracking shear stress $\tau_{\text {uc }}$.

$$
\frac{\mathrm{V}_{\mathrm{uc}}}{\mathrm{bd} \sqrt{\mathrm{f}_{\mathrm{cu}}}}=0.16+17.2 \frac{\mathrm{pV}_{\mathrm{cr}} \mathrm{d}}{\mathrm{M}_{\mathrm{cr}} \sqrt{\mathrm{f}_{\mathrm{cu}}}}
$$

Where

$\mathrm{V}_{\mathrm{cr}}=$ Cracking load in $\mathrm{KN}$

$\mathrm{p}=$ Reinforcement ratio $=\mathrm{A}_{\mathrm{st}} / \mathrm{bd}$

$\mathrm{A}_{\mathrm{st}}=$ Area of steel in $\mathrm{mm}^{2}$

$\mathrm{M}_{\mathrm{c} \mathrm{r}}=$ Bending moment $\mathrm{N}-\mathrm{mm}$

\section{2) As per CIRIA Guide:}

$$
\frac{\mathrm{V}_{\mathrm{uc}}}{\mathrm{bh}}=\lambda_{1} \times \mathrm{V}_{\mathrm{x}}+\beta\left(\mathrm{V}_{\mathrm{ms}}+\mathrm{V}_{\mathrm{oh}}+\mathrm{V}_{\mathrm{wv}}\right)
$$

Where

$\lambda_{1}=0.44$ for normal weight concrete.

$\mathrm{V}_{\mathrm{x}}=\quad$ concrete shear parameter as tabulated in table -4 of the CIRIA guide.

$\mathrm{V}_{\mathrm{ms}}=\quad$ Main steel shear stress parameter as tabulated in Table -6 of the CIRIA guide.

$\mathrm{Vwh}=$ Horizontal web steel as tabulated in table -7 of the CIRIA guide

Vwv $=\quad$ Vertical web steel as tabulated in table -8 of the CIRIA guide

$\beta=1$ for deformed bars.

\subsection{Proposed equation by Mau \& Hsu:}

The ultimate shear strength is given by

$\mathrm{V}_{\mathrm{n}}=\frac{1}{2} \mathrm{f}_{\mathrm{c}}\left[\mathrm{K}\left(\omega_{\mathrm{h}}+0.03\right)+\sqrt{\mathrm{K}^{2}\left(\omega_{\mathrm{h}}+0.03\right)^{2}+4\left(\omega_{\mathrm{v}}+0.03\right)}\right] \leq 0.3 \mathrm{f}_{\mathrm{c}}{ }^{\prime}$

(5)

With the limitations $\omega_{\mathrm{h}}=\rho_{\mathrm{h}} \mathrm{f}_{\mathrm{y}} / \mathrm{f}_{\mathrm{c}}{ }^{\prime} \leq 0.26$ and $\rho_{\mathrm{v}} \mathrm{f}_{\mathrm{y}} / \mathrm{f}_{\mathrm{c}}{ }^{\prime} \leq 0.2$. The coefficient $\mathrm{K}$, representing the shear span effect, is given by.

$$
\mathrm{K}=2 \frac{\mathrm{d}_{\mathrm{v}}}{\mathrm{h}} \text { for } 0<\mathrm{a} / \mathrm{h} \leq 0.5
$$

$$
\begin{gathered}
\mathrm{K}=\frac{\mathrm{d}_{\mathrm{v}}}{\mathrm{h}}\left[\frac{\mathrm{h}}{\mathrm{a}}\left(\frac{4}{3}-\frac{2 \mathrm{a}}{3 \mathrm{~h}}\right)\right] \text { for } 0.5<\mathrm{a} / \mathrm{h} \leq 2.0 \\
\mathrm{~K}=0 \text { for } \mathrm{a} / \mathrm{h}>2.0
\end{gathered}
$$

\subsection{Empirical formula for the ultimate strength of}

\section{ferrocement deep beams:}

The ultimate strength depends upon the following parameters.
a. Mortar strength $\left(\mathrm{f}_{\mathrm{cu}}\right)$.
b. Ratio of shear span to the depth $(\mathrm{a} / \mathrm{h})$
c. Volume fraction of reinforcement $\left(\mathrm{V}_{\mathrm{f}}\right)$

From the earlier discussion it is clear that, a separate formula for predicting the diagonal cracking strength of ferrocement elements is necessary.

Shear resistance of ferrocement elements is mainly due to the contribution of mortar matrix and longitudinal reinforcement. The results of the present tests are compared. It shows that there is large difference between the experimental values with the code values. The ACI code formula Eq. (1) greatly underestimates the diagonal cracking strength for most of the beams. In an attempt to develop an expression which might predict more closely the diagonal cracking strength of beams over the entire range of parameters covered in this investigation, the following expression, which is similar to the one proposed by Zsutty, was selected.

$$
\frac{V_{u}}{b h}=K\left(f_{c u} V_{f} \frac{h}{a}\right)^{n}
$$

Where $\mathrm{K}$ and $\mathrm{n}$ are constant and $\mathrm{f}_{\mathrm{cu}}$ is expressed in $\mathrm{N} / \mathrm{mm}^{2}$. A multiple regression analysis was carried out using the results of the present tests, which yields $K=2.227$ and $n=0.80$.

$$
\frac{\mathrm{V}_{\mathrm{u}}}{\mathrm{bh}}=2.227\left(\mathrm{f}_{\mathrm{cu}} \mathrm{V}_{\mathrm{f}} \frac{\mathrm{h}}{\mathrm{a}}\right)^{0.80}
$$

This is the required expression for estimating the ultimate shear capacity of ferrocement deep beams. Using this equation the shear stress of the tested beams are computed and compared with observed and proposed value. The average of the observed to the proposed values is 1.631 with S.D. of 0.548 and that of observed to the predicted values is 0.97 with S.D of 0.268. The correlation coefficient for the present test is. 0.768 .

\section{CONCLUSIONS}

The diagonal cracking strength of ferrocement increases as the $\mathrm{a} / \mathrm{h}$ ratio is decreased or volume fraction of reinforcement and strength of the mortar are increased. Ferro cement deep beams 
demonstrate excellent crack control characteristics. The empirical formula $\left(\frac{\mathrm{V}_{\mathrm{u}}}{\mathrm{bh}}=2.227\left(\mathrm{f}_{\mathrm{cu}} \mathrm{V}_{\mathrm{f}} \frac{\mathrm{h}}{\mathrm{a}}\right)^{0.8}\right)$ proposed here in terms of $h$ and $V_{f}$ provide good predictions of the diagonal cracking strength for the entire range of variables considered in this study.

\section{REFERENCES}

[1]. Al-Kubaisy. M.A., and Nedwell, P.J., Location of Critical Diagonal Crack in Ferrocement Beams, Journal of Ferrocement, 28 (1998)

[2]. Mansur, M.A. and Ong, K.C.G. 1987. Shear strength of ferrocement beams. ACI Structural Journal 84(1): 10-17.

[3]. Naaman, A.E.; and Shah, S.P., "Tensile Tests of Ferrocement," ACI Journal, Proceeding V.68, No. 9, Sept. 1971, pp. 693-698.

[4]. Desayi, P., and Nandakumar, N., A semi-empirical approach to predict shear strength of ferrocement, Cement and Concrete Composities, 17(1995) 207-218.

[5]. Mansur M.A., Paramasivam, P., 1986. Study of Sandwich Wall Panels Journal of Ferro cement 16(3): 295-313. 